\title{
Science advisers face 'credibility crisis'
}

[WASHINGTON] A group of leading environmental scientists was warned last week by two senior congressional staff members that a series of politically charged debates in coming months could exacerbate a continuing "crisis of credibility" for scientists who advise policymakers.

The congressional officials also said that scientists should make a point of meeting members of Congress and their staff members to explain not only the benefits of science, but also its limitations in helping to resolve difficult social issues.

The advice came in an unusual hour-long briefing to the executive committee of the Environmental Protection Agency (EPA)'s Science Advisory Board, the congressionally mandated 100-member body of outside experts that reviews research produced by the agency and its contractors.

The executive committee invited both Republican and Democratic staff members to the briefing, but only representatives of the minority Democratic party were able to attend. They were Michael Rodemeyer, chief Democratic counsel to the House of Representatives Science Committee, and Thomas Sliter, minority staff director for the Senate Committee on Environment and Public Works.

Both said their remarks reflected their personal opinions rather than those of their respective committees. But they agreed that, despite a broad respect for science among politicians, there is "a very disturbing confusion between science and policy" in Congress.

"Congress expects too much of science," said Rodemeyer, and is often puzzled or angry

\section{Staff cuts proposed for energy department}

[WASHINGTON] A panel of highranking Department of Energy (DoE) officials and outside advisers is calling for a major reduction in the size of the agency's headquarters and field management

bureaucracy, as a step towards improved efficiency of the US system of national laboratories.

In a report expected to be made public next month, the department's Laboratory Operations Board says that the agency's current structure, which is widely seen as a left-over from the Cold War, is no longer appropriate in the light of technological advances that have improved long-distance communications. It calls for "appropriate consolidations" between headquarters and field management staff.

"Field operations seem to be largely process-oriented rather than mission-oriented," says the report. It adds that the problem is compounded by the fact that the field offices report to a separate headquarters field management office, rather than to the agency programmes that fund the laboratories. Energy department laboratories report to field offices that are usually nearby, but funding is provided by programme offices at headquarters.

The report, $R \& D$ Program

ManagementReviews, is a

follow-up to a Strategic

Laboratory Missions Plan released by the agency last

summer. It is intended to advise programme managers at DoE on whether they are using the right mix and number of R\&D performers namely the laboratories, universities and industry.

Both reports are followons to the February 1995 report by the panel known as the Galvin Task Force, which also recommended a major reduction of the DoE system of laboratory management.

The report of the operations board calls for more planning across DoE programmes, and recommends that the laboratories should be operated more as a system, sharing work when it makes sense and making specialists available for short-term projects, regardless of which laboratory or DoE organization has the need. It says the laboratories should consider combining their management functions to cut costs and improve quality.

For DoE's Office of Energy Research, which operates the department's five non- weapons multi-programme laboratories, as well as its accelerator and fusion research facilities, the report suggests that maximizing the use of the user facilities of those laboratories should be a high priority.

These facilities, which include synchrotrons, neutron sources and other highly specialized experimental equipment, are available to outside researchers for nonproprietary research. The panel claims that they are responsible for important advances in "pushing the frontiers of discovery in a wide variety of fields".

Arguing that there is "no overarching roadmap" for the future of such facilities, the board urges a broad study into the needs for and strategy surrounding them over the coming $15-20$ years. The review, which should be completed by March 1998, should encompass all fields of research covered by the DoE, including high-energy and nuclear physics, condensed-matter and materials science, life sciences and global climate change. It should also consider whether international cooperation is appropriate. when scientists cannot deliver a single, clear answer to some difficult environmental question such as how clean-air laws should be written. Scientific uncertainty "may be one of the most difficult concepts for Congress to deal with", said Sliter.

The risk for scientists is that uncertainty becomes expressed in public in an adversarial way, with "duelling experts" giving conflicting testimonies that cancel each other out. According to Rodemeyer, this contributes to a growing perception among politicians and the public that "science really doesn't have anything to contribute to policy debates".

Both said that one solution is for scientists, both in groups and as individuals, to educate congressional members and their staff behind the scenes. "There is no substitute on Capitol Hill for face-to-face meetings," said Rodemeyer.

Sliter predicted that proposed EPA regulations on pollution from ozone and airborne particulates will be a "very hot political issue" in this Congress (see Nature 384, 392; 1996). His committee will hold hearings on the subject next month.

Many controversial environmental issues left unresolved by the previous Congress such as the protection of endangered species and wetlands, and clean water - will also be up for discussion. The debate is expected to be less hostile this year than last. But Republicans are still expected to oppose tighter environmental regulation.

Meanwhile, EPA's Science Advisory Board is struggling over how to handle the controversy that frequently arises from its reports. Several members of the board's Clean Air Scientific Advisory Committee, which was divided in its review of the proposed EPA regulations on ozone and particulates, have publicly expressed doubts about the scientific foundations of the new rules.

In a draft report prepared last month, the subcommittee agreed that board members should always be careful to distinguish between personal views and a committee's view, and should stand behind a report once it is completed.

Meanwhile, as it braces itself for the congressional debate on clean-air laws, EPA also is continuing to work on ways to shore up its scientific credibility. The Office of Research and Development (ORD) - the main producer of basic environmental research in an agency that is primarily geared toward regulation - was given authority last week to review the way in which other EPA offices responsible for air, water and solid-waste and other regulations conduct peer review of their research products. That gives Robert Huggett, the head of ORD and a respected scientist, more oversight of the agency's research. 